Annals of Plant and Soil Research 22(4): 349-353 (2020)

https://doi.org/10.47815/apsr.2020.10003

\title{
Effect of integrated nutrient management on yield and uptake of nutrients in pearl millet (Pennisetun glaucum)- mustard (Brassica juncea) crop sequence
}

\author{
VINAY SINGH \\ Department of Agricultural Chemistry and Soil Science, Raja Balwant Singh College, Bichpuri, Agra (U.P.)- \\ 283105
}

Received: July, 2020, Revised accepted; September, 2020

\begin{abstract}
A field experiment was conducted at Panwari Village of Agra district (U.P.) during 2015-16 and 2016-17 to evaluate the effect of integrated nutrient management in pearl millet (Pennisetum glaucum L.)- Indian mustard (Brassica juncea $L$ ) crop sequence. The experiment was laid out in randomized block design with six treatments and three replications. The results revealed that the application of $100 \%$ recommended dose of $N, P$ and $K$ fertilizers recorded significantly higher grain $\left(4.10 \mathrm{tha}^{-1}\right)$ and stover $\left(10.72 \mathrm{t} \mathrm{ha} \mathrm{H}^{-1}\right)$ yields of pearl millet over $75 \%$ NPK and control. The yield (4.02 and $0.40 \mathrm{tha}^{-1}$ ) of pearl millet obtained with $75 \%$ NPK +10 t FYM ha ${ }^{-1}+$ Azotobacter, was at par with $100 \%$ NPK fertilizers. Application of 10 t FYM ha ${ }^{-1}$ was also found to be beneficial in terms of yield of the crop over control. The protein content in pearl millet grain (10.6\%) was higher under $100 \%$ NPK treatment over other treatments. Similarly, the uptake of nutrients (N, P and K) by pearl millet crop was significantly higher under $100 \%$ N, P and K fertilizers over control. The yield of succeeding mustard crop increased significantly under the treatment in which previous pearl millet crop had 10 t $F Y M$ ha $^{-1}$ along with $75 \%$ NPK fertilizer and Azotobacter. Residual effect of 10t FYM ha ${ }^{-1}$ along with 75\% NPK and Azotobacter produced the maximum seed and stover yield of mustard which was $15.1 \%$ higher in seed and $15.4 \%$ in stover production over $100 \%$ NPK alone, respectively. The quality of mustard seed (oil content) was significantly higher with combined use of organics and fertilizers. The uptake of nutrients by mustered crop was significantly higher under residual effect of integrated use of organic and inorganic fertilizer over other treatments.
\end{abstract}

Keywords: Integrated nutrient management, pearl millet-mustard crop sequence, yield

\section{INTRODUCTION}

Pearl millet- mustard crop sequence is predominant in North-Western India especially, Rajasthan, Uttar Pradesh, Haryana and Madhya Pradesh, because of its high productivity and profitability. This crop sequence is also important as it requires low water, inputs and labour in comparison to other pearl millet based systems. Our soils have been exhausted in respect of major and minor elements hampering the yield of crops. Proper and optimum application of fertilizers not only increases the yield but also faourably affects the quality of the produce. To curb this trend of declining yield, there is need to adopt the concept of integrated nutrient management. The concept of integrated nutrient management has emerged as an important tool for maintaining soil fertility, crop productivity which requires optimum use of organic, inorganic and bio-source of plant nutrients. The best of inorganic could be obtained in the presence of adequate organic manures and that maximum pearl millet and mustard yield could be obtained through complementary use of organic and inorganic fertilizers. With the application of recommended dose of fertilizers, yield potential of this crop sequence (cereal- oil Seed) has reached to a plateau because soil health has deteriorated and especially organic matter has depleted. Organic manure (FYM) also supplies the traces of micro nutrients which are not supplied by chemical fertilizers. Bio-fertilizers have also emerged promising components of integrated nutrient supply system which are environment friendly and low cost inputs. Application of all the needy nutrients through chemical fertilizers has deleterious effect on soil health, leading to unsustainable yields. Therefore, there is need to improve nutrient supply system for sustaining production of this very important crop sequence. Hence, a study was undertaken to evaluate the effect of integrated nutrient management on yield, quality and uptake of nutrients in pearl millet-mustard crop sequence. 


\section{MATERIALS AND METHODS}

Field experiment was conducted during 2014-15 and 2015-16 at Panwri Village of Agra district. The site of this experiment is characterized by semi-arid climate with hot dry summers (48 to $48^{\circ} \mathrm{C}$ ) and very low temperature during winter (as low as $2^{\circ} \mathrm{C}$ ). The average rainfall is about $650 \mathrm{~mm}$, of which a major portion of $546 \mathrm{~mm}(84 \%)$ is received from July to September and only $104 \mathrm{~mm}(16 \%)$ is received in the remaining part of the year. The soil was sandy loam in texture having $\mathrm{pH}$ value of 8.1 , poor in available $\left.\mathrm{N}(145 \mathrm{~kg} \mathrm{ha})^{-1}\right)$, low in phosphorus $\left(9.4 \mathrm{~kg} \mathrm{ha}^{-1}\right)$ and available $\mathrm{K}(108 \mathrm{~kg}$ $\left.\mathrm{ha}^{-1}\right)$. The experiment was laid out in randomized block design with six treatments viz. $\mathrm{T}_{1}$ Control, T2 $75 \%$ recommended dose of $\mathrm{N}, \mathrm{P}$ and $\mathrm{K}, \mathrm{T}_{3}$ 10t FYM ha ${ }^{-1}, \mathrm{~T}_{4} 75 \%$ RDF + 10 t FYM ha ${ }^{-1}, \mathrm{~T}_{5}$ $75 \%$ RDF + 10 t FYM ha ${ }^{-1}+$ biofertilizer and $\mathrm{T}_{6}$ $100 \%$ RDF and three replications. Different treatments were tried during Kharif season while in Rabi season only residual effect on succeeding mustard (var. Bio-902) crop was seen. The FYM $(0.55 \% \mathrm{~N}, 0.21 \% \mathrm{P}$ and $0.73 \%$ $\mathrm{K})$ as per treatment was incorporated to soil one week before sowing of pearl millet crop. All amounts of phosphorus and potassium and half dose of nitrogen as per treatment were applied at the time of sowing and rest of nitrogen was top dressed at first irrigation. Urea, single superphosphate and muriate of potash were used as sources of $\mathrm{N}, \mathrm{P}$ and $\mathrm{K}$, respectively. Pearl millet seed $\left(5 \mathrm{~kg} \mathrm{ha}^{-1}\right)$ was sown in first week of July during both the years. After harvest of pearl millet, mustard crop was sown in second week of November in the same layout. Pearl millet and mustard crops were harvested in last week of September and last week of March in both years, respectively. In mustard crop, two irrigations were applied each year. Recommended package of practices were followed for both the crops. At harvest grain / seed and stover yields were recorded. The grain / seed and stover samples were digested using di acid mixture of $\mathrm{HNO}_{3}: \mathrm{HClO}_{4}$ (10: 4). Phosphorus and $\mathrm{K}$ content in acid extract were determined by vanadomolydo phosphoric yellow color method and flame photometer, respectively (Jackson, 1973). Nitrogen content was determined by adopting modified Kjeldahl method.The uptake of nutrients was computed from the data on nutrient concentration multiplied by yields of both the crops. The oil content in mustard seeds was determined by using Soxhlet apparatus. The trend of results was similar during both the years hence data were subjected to pooled analysis for results and discussion. The data generated for both the crops were statistically analyzed (Gomez and Gomez 1984).

\section{RESULTS AND DISCUSSION}

\section{Pearl Millet}

Yield: Application of organic and inorganic sources of nutrients increased the grain and stover yield of pearl millet and maximum grain (4.10t ha $\left.\mathrm{h}^{-1}\right)$ and stover $\left(10.72 \mathrm{t} \mathrm{ha} \mathrm{h}^{-1}\right)$ yield was recorded with $100 \%$ NPK. The increase in yield may be attributed to increased availability of nutrients (Singh 2019). Significantly higher pooled grain $\left(4.02 \mathrm{t} \mathrm{ha}^{-1}\right)$ and stover $\left(10.40 \mathrm{t} \mathrm{ha}^{-1}\right)$ yield of pearl millet was recorded in $75 \%$ NPK + 10 t FYM ha $^{-1}$ + Azotobactor treated plots over the other treatments (Table 1). The increase in yield in the treatments receiving FYM might be due to the fact that FYM not only provided additional nutrients other than $\mathrm{N}, \mathrm{P}$ and $\mathrm{K}$ but also improved the physical properties of soil (Singh et al. 2013). Application of $10 \mathrm{t} \mathrm{FYM} \mathrm{ha}^{-1}$ showed better results in respect to yield over control as reported by Singh and Patra (2017). The yields of pearl millet under the treatment $75 \%$ NPK + 10 t FYM + Azotobacter were at par with $100 \%$ NPK. It shows that there is a net saving of $25 \% \mathrm{~N}, \mathrm{P}$ and $\mathrm{K}$ fertilizers ha ${ }^{-1}$ through organic sources i.e. FYM and biofertilizer. Twenty five percent N, P and $\mathrm{K}$ through chemical fertilizers could be substituted without any adverse effect on yield of pearl millet with organic sources have also been reported by Pandey et al. (2020). The lowest values of grain and stover yields of pearl millet were registered in control which may be due to less availability of nutrients from soil.

Protein: The protein content in grain of pearl millet showed an increasing trend under different treatments over control (Table 1). The protein content in grain increased from $10.1 \%$ at control to $10.6 \%$ with $100 \%$ NPK treatment. Application of FYM alone and in combination with fertilizers and bio-fertilizers proved significantly beneficial in promoting the percentage of protein in pearl millet grain. This may be due to accumulation of 
more nitrogen with these treatments and ultimately showing more protein content. Application of $10 \mathrm{t} \mathrm{FYM} \mathrm{ha}^{-1}$ alone also improved the protein content in pearl millet grain over control. Similar results were reported by Singh (2019) and Pandey et al. (2020).

Table 1: Effect of integrated nutrient management on yields $\left(\mathrm{t} \mathrm{ha}^{-1}\right)$ and quality of pearl millet and mustard (mean of 2 years)

\begin{tabular}{|c|c|c|c|c|c|c|}
\hline \multirow{2}{*}{ Treatment } & \multicolumn{3}{|c|}{ Pearl millet } & \multicolumn{3}{|c|}{ Mustard } \\
\hline & Grain & Stover & Protein (\%) & Seed & Stover & Oil content (\%) \\
\hline Control & 1.87 & 5.38 & 10.1 & 1.27 & 3.05 & 39.0 \\
\hline $75 \%$ NPK & 3.40 & 9.05 & 10.3 & 1.55 & 3.72 & 39.9 \\
\hline 10t FYM ha ${ }^{-1}$ & 2.66 & 7.16 & 10.2 & 1.66 & 3.96 & 40.5 \\
\hline $75 \%$ NPK + 10t FYM ha ${ }^{-1}$ & 3.92 & 10.00 & 10.4 & 2.00 & 4.58 & 41.5 \\
\hline 75\% NPK + 10t FYM + Azot. & 4.02 & 10.40 & 10.5 & 2.05 & 4.90 & 41.5 \\
\hline $100 \%$ NPK & 4.10 & 10.72 & 10.6 & 1.78 & 4.25 & 40.4 \\
\hline$C D(P=0.05)$ & 0.46 & 1.13 & 0.19 & 0.09 & 0.16 & 0.11 \\
\hline
\end{tabular}

Uptake of nutrients : The uptake of $\mathrm{N}$ by grain and stover increased significantly by various levels of N,P and $K$ fertilizers and higher values of $\mathrm{N}$ uptake by grain $\left(69.7 \mathrm{~kg} \mathrm{ha}^{-1}\right)$ and stover $\left(57.8 \mathrm{~kg} \mathrm{ha}^{-1}\right)$ of pearl millet was recorded with $100 \%$ NPK treatment. This may be attributed to increased grain and stover yield of pearl millet and $\mathrm{N}$ content owing to increased availability of $\mathrm{N}$ to the crop (Singh 2019). Application of $75 \%$ NPK + 10 t FYM ha $^{-1}$ + bio-fertilizer resulted in significantly higher uptake of $\mathrm{N}$ by the pearl millet crop. Application of $75 \%$ NPK +10 t FYM ha $^{-1}$ also obtained at par results with $75 \%$ NPK + 10t FYM ha ${ }^{-1}$ + bio-fertilizer. This increase in $\mathrm{N}$ uptake may be due to increased availability of $\mathrm{N}$ to the plants as well as improved soil environment. Similar results were reported by Singh et al. (2013) and Kamble et al. (2018). Higher uptake of $P$ by pearl millet grain and straw was registered under application of $100 \%$ NPK treatment (Table 2). The data further showed that application of FYM along with $75 \%$ NPK resulted almost comparable uptake of $P$ by the crop to $100 \%$ NPK treatment. This increase in $P$ uptake might be due to the solubilization effect of FYM on native phosphorus. Higher uptake of $P$ with the use of organic manures has also been reported by Kamble et al. (2018). The lowest uptake of $P$ by the crop was recorded under control treatment due to less amount of available $P$ in soil. Significantly higher uptake of $\mathrm{K}$ by pearl millet grain and stover was recorded with $100 \%$ NPK treatment as compared to $75 \%$ NPK and control. This increase in K uptake may be attributed to increased yields and $\mathrm{K}$ content in grain and stover Singh (2019). Application of $\mathrm{FYM}+75 \% \mathrm{NPK}$ + bio-fertilizer increased the K uptake by the crop over other treatments. The higher uptake of $\mathrm{K}$ in the treatments receiving FYM could be due to the increased $K$ availability in soil. An integrated application of FYM and inorganic fertilizers showed higher uptake of $\mathrm{K}$ compared to that of soil FYM application due to the increased $\mathrm{K}$ availability (Kamble et al. 2018).

Mustard: The seed and stover yield of mustard increased with $100 \%$ NPK over $75 \%$ NPK and control. Application of $100 \%$ NPK increased the seed and stover yield by 40.1 and 39.3 per cent, respectively over control owing to greater availability of nutrients to plants (Kumar and Singh 2019). Application of $10 \mathrm{t} \mathrm{FYM} \mathrm{ha-1} \mathrm{in} \mathrm{pearl}$ millet crop produced higher seed and stover yield over control (Table 1). It may be due to residual effect of FYM applied to pearl millet as compared to control. These results are supported by the findings of Chandel et al. (2018) The data further showed that organics along with $75 \%$ NPK fertilizers produced maximum seed $\left(2.05 \mathrm{t} \mathrm{ha}^{-1}\right)$ and stover (4.90t ha$\left.{ }^{1}\right)$ yield over other treatment. The enhanced crop yield might be due to addition of nutrients and improvement in physical, chemical and biological properties of the soil by supplying organic matter. This increase in yield may be ascribed to overall improvement in plant organs associated with higher growth of crop under residual effect of organic sources. It is in conformity with the results reported by Chauhan et al. (2018). 
Table 2: Effect of integrated nutrient management on uptake of nutrients $\left(\mathrm{kg} \mathrm{ha}^{-1}\right)$ in pearl millet (mean of 2 years)

\begin{tabular}{l|ccc|cc|cc|}
\hline \multirow{2}{*}{ Treatment } & \multicolumn{2}{c|}{ Nitrogen } & \multicolumn{2}{c|}{ Phosphorus } & \multicolumn{2}{c|}{ Potassium } \\
\cline { 2 - 7 } & Grain & Stover & Grain & Stover & Grain & Stover \\
\hline Control & 30.4 & 25.8 & 4.3 & 6.4 & 10.2 & 97.8 \\
75\% NPK & 56.1 & 45.2 & 8.5 & 12.6 & 19.3 & 166.5 \\
10t FYM ha ${ }^{-1}$ & 43.6 & 35.0 & 6.3 & 9.3 & 14.8 & 131.0 \\
75\% NPK + 10t FYM ha & -1 & 65.4 & 52.0 & 10.5 & 15.0 & 23.0 & 185.0 \\
$75 \%$ NPK + 10t FYM + Azot. & 68.5 & 55.1 & 10.8 & 15.6 & 23.3 & 192.4 \\
100\% NPK & 69.7 & 57.8 & 11.4 & 16.1 & 24.6 & 200.0 \\
CD (P=0.05) & 3.78 & 3.15 & 1.10 & 1.27 & 2.20 & 8.85 \\
\hline
\end{tabular}

Oil Content: The results (Table 1) indicated that the application of various treatments had significantly beneficial effect on oil content in mustard seed over control. The maximum oil content $(41.5 \%)$ in mustard seeds was recorded under the residual effect of $75 \% \mathrm{NPK}+10 \mathrm{t} \mathrm{FYM}$ $\mathrm{ha}^{-1}+$ bio-fertilizer while minimum (39.0\%) in control treatment. Similar results were made by
Chandan et al. (2018). Application of 75\% NPK + 10t FYM ha ${ }^{-1}$ was statistically at par with $75 \%$ $\mathrm{NPK}+10 \mathrm{t} F Y M$ + bio-fertilizer in respect of quantity of oil in mustard seed. Increasing levels of NPK fertilizers from control to $100 \%$ NPK also improved the oil content in mustard seed (Sharma et al. 2017).

Table 3: Effect of integrated nutrient management on uptake of nutrients $\left(\mathrm{kg} \mathrm{ha}^{-1}\right)$ in mustard (mean of 2 years)

\begin{tabular}{|c|c|c|c|c|c|c|}
\hline \multirow{2}{*}{ Treatment } & \multicolumn{2}{|c|}{ Nitrogen } & \multicolumn{2}{|c|}{ Phosphorus } & \multicolumn{2}{|c|}{ Potassium } \\
\hline & Seed & Stover & Seed & Stover & Seed & Stover \\
\hline Control & 36.8 & 19.8 & 7.3 & 5.5 & 7.6 & 57.9 \\
\hline $75 \%$ NPK & 45.5 & 54.9 & 9.3 & 7.0 & 9.4 & 71.4 \\
\hline 10t FYM ha ${ }^{-1}$ & 48.4 & 26.1 & 10.0 & 7.9 & 10.1 & 76.0 \\
\hline $75 \%$ NPK + 10t FYM ha ${ }^{-1}$ & 59.2 & 31.6 & 12.2 & 9.1 & 12.4 & 88.3 \\
\hline $75 \%$ NPK + 10t FYM + Azot. & 60.1 & 34.3 & 12.7 & 10.3 & 12.7 & 94.5 \\
\hline $100 \%$ NPK & 53.4 & 30.1 & 10.8 & 8.5 & 10.8 & 91.1 \\
\hline$C D(P=0.05)$ & 4.10 & 2.61 & 0.22 & 0.17 & 1.15 & 5.49 \\
\hline
\end{tabular}

Uptake of Nutrients: The uptake of nutrients ( $N$, $P$ and $K$ ) in seed and stover of mustard increased significantly with residual effect of 75 and $100 \%$ NPK treatments over control. This may be due to better availability of nutrients and improvement in soil environment (Chandan et al. 2018). Application of $75 \%$ NPK + 10 t FYM ha $^{-1}$ + Azotobacter resulted in maximum utilization of nitrogen by seed $\left(60.1 \mathrm{~kg} \mathrm{ha}^{-1}\right)$ and stover $(34.3$ $\left.\mathrm{kg} \mathrm{ha}^{-1}\right)$. The residual effect of FYM $+75 \%$ NPK also resulted in increased $\mathrm{N}$ uptake by the crop. Residual effect of FYM alone also had significantly beneficial effect on the utilization of nitrogen by mustard crop. Higher values of $\mathrm{N}$ uptake by the crop with FYM application are apparently the result of favourable effect of FYM on $\mathrm{N}$ absorption couplet with greater yield (Kumar and Singh 2019). Residual effect of either $100 \%$ NPK or $25 \%$ reduced RDF $(75 \%$ NPK) recorded significantly higher $P$ uptake by mustard crop. This increase in $\mathrm{P}$ uptake may be attributed to increased $P$ concentration coupled with higher yield (Sharma et al. 2017). Significantly higher $\mathrm{P}$ uptake by mustard seed $\left(12.7 \mathrm{~kg} \mathrm{ha}^{-1}\right)$ and stover $\left(10.3 \mathrm{~kg} \mathrm{ha}^{-1}\right)$ was observed with residual effect of $75 \% \mathrm{NPK}+10 \mathrm{t}$ FYM ha ${ }^{-1}+$ bio-fertilizer. Application of 10 t FYM ha $^{-1}$ applied in pearl millet crop also improved the $P$ uptake by crop over control. The addition of organic matter resulted in increased $P$ uptake because addition of organic sources of nutrients (FYM and bio-fertilizer) resulted in solubilization of insoluble native phosphate and thus higher availability of phosphorus to plants. Similar results were reported by Chandan et al. (2018). Increasing levels of NPK fertilizers increased the uptake of $\mathrm{K}$ by seed and stover of mustard over control and relatively higher uptake values were noted with $100 \%$ NPK treatment as reported by Sharma et al. (2017). The uptake of $\mathrm{K}$ by 
mustard was found positive in the treatments where integration of inorganic and organic fertilizers was tried. The maximum uptake of $\mathrm{K}$ by seed $\left(12.7 \mathrm{~kg} \mathrm{ha}^{-1}\right)$ and stover $\left(94.5 \mathrm{~kg} \mathrm{ha}^{-1}\right)$ was registered under $75 \% \mathrm{NPK}+10 \mathrm{t} \mathrm{FYM} \mathrm{ha}^{-1}$ + bio-fertilizer treatment, which may be ascribed to higher availability of $\mathrm{K}$ to the plants. Moreover, higher amount of $K$ was received in stover than seed, it was merely because of higher content of $\mathrm{K}$ in stover of the crop (Chauhan et al. 2018).

\section{REFERENCES}

Chandan, S. K., Singh, S. K., Pandey, A., Singh, $P$ and Prabha, S. (2018) Effect of integrated nutrient management on growth, yield and nutrient uptake by Indian mustard (Brassica juncea L). Annals of Plant and Soil Research 20(1): 31-36.

Chauhan, S.K., Singh, S.K., Pandey, A., Singh, $P$ and Snehprabha (2018) Effect of integrated nutrient management on growth, yield and nutrient uptake by Indian mustard (Brassica juncea). Annals of Plant and Soil Research 20(1) : 31-36.

Gomez, K.A. and Gomez, A.A. (1984) Statistical Procedures for Agricultural Research. A Wiley Inter science Publication, John Wiley and Sons, New York

Jackson, M.L. (1973) Soil Chemical Analysis.Prentice Hall of India Private Limited, New Delhi.

Kamble, B.M., Kathmale, D.K. and Rathod, S.D. (2018) Soil nutrient status, uptake, yield and economics of groundnut - wheat cropping sequence as influenced by organic sources and fertilizers. Journal of the Indian Society of Soil Science 66(1) : 66-75.

Kumar, V. and Singh, S. (2019) Effect of fertilizers, biofertilizers and farmyard
From the results, it can be concluded that integrated use of FYM, inorganic fertilizer and bio-fertilizer resulted in getting higher yields and quality of produce in pearl millet-mustard cropping sequence. It clearly indicated that, $25 \%$ recommended dose of $\mathrm{N}, \mathrm{P}$ and $\mathrm{K}$ fertilizers can be saved with FYM. Integrated use of FYM and fertilizers also improved the utilization of nutrients in both the crops.

manure on sustainable production of Indian mustard (Brassica juncea). Annals of Plant and Soil Research 21(1) : 25-29.

Pandey, M., Kumar, S. and Singh, U.N. (2020) Effect of integrated nutrient management on productivity of oat (Avena sativa) and soil fertility. Annals of apalant and Soil Research 22(2): 151-155

Sharma, J.K., Jat, G., Meena, R.H., Purohit, H.S. and Choudhary, R.S. (2017) Effect of vermicompost and nutrients application on soil properties, yield, uptake and quality of Indian mustard (Brassica juncear). Annals of Plant and Soil Research 19(1): 17-22.

Singh, M.V., Kumar, N. and Mishra, B.N. (2013) Integrated use of nitrogen and FYM on yield, nutrient uptake and economics of maize in eastern Uttar Pradesh. Annals of Plant and Soil Research 15(2): 128130.

Singh, V. (2019) Effect of nutrient management on yield, uptake of nutrients and soil fertility under pearl millet (Pennisetum glaucum)-wheat (Triticum aestivum) crop sequence. Annals of Plant and Soil Research 21(2): 149-153. 